Gut, 1964, 5, 412

\title{
Peptic ulcer in India and its aetiology
}

\author{
S. L. MALHOTRA \\ From the Medical Department, Western Railway, Bombay, India
}

SYNOPSIS A study of the incidence of peptic ulcer amongst railway workers in various parts of India has shown that ulcer is more common in wet and humid areas than in the dry and arid regions. This observation is also supported by the ulcer incidence reported in other studies from India, Africa, and the West.

Saliva appears to have an important role in the prevention of ulcer, because of its rich content of blood group antigens. There may be unrecognized factors in the saliva which may be ulcerogenic and others which prevent ulcer. Parasympathetic overaction also appears to contribute to ulcer formation due to its effect on salivation, sexual activity, and stress and strain.

The prevalence of peptic ulcer in India shows striking variations, the disease being common in some parts of the country and rare in others (Somervell and Orr, 1936; Dogra, 1940). The ulcer is uncommon in the Punjab but the disease as so far reported from the Punjab is rare in the arid plains though by no means uncommon in the humid hill districts of Kangra, being 12 times more common than in the plains (Wig, 1959; Chuttani and Saigal, 1958). Hadley (1959) had noted similar variations in the incidence of the disease in various parts of the country: Ludhiana (Punjab) $\mathbf{0 . 2} \%$, Srinagar (Kashmir) $2.5 \%$, and Vellore (south India) $1.6 \%$.

\section{METHODS AND MATERIAL}

CLINICAL DATA The clinical data are derived from the hospital admissions to the various railway hospitals in the country during 1960 (Table I). Outpatients have not been included in this study as out-patient records have the serious disadvantage of being less precise. Figures for peptic ulcer perforations have also been collected for the year 1960 . Perforation is a particularly painful and serious disease and expedites the hospital admission of almost all in whom it develops and, therefore, such data are a useful index of the prevalence of peptic ulcer in a given area.

The data on prevalence of ulcer in India and elsewhere as reported in other studies have also been collected and are set out in Table II.

GEOGRAPHY AND CLIMATE India has extremes of temperature. The north has a severe summer and a severe winter; the south and the coastal areas are warm all the year round and the hill districts are cold all the year round. The variations in rainfall and humidity in the different parts of the country are also considerable. The humidity varies from the low figure of $40 \%$ to the high figure of $90-100 \%$. These facts for different places are shown in Tables I and II and in Figure 1.

DIET The staple diets differ widely from place to place. In the south, tapioca, boiled rice as such or pressed in the form of cakes, called idlees, and hot dal curries, called sambhar, are eaten. In Bengal the staple food is boiled rice and fish curry. In Kashmir and in the hill districts of the Punjab, the staple diet is boiled rice and dal. In Rajasthan (Meenas and Dangas of Mewar) the diet is boiled corn and maize gruel or maize Batti which is prepared by slowly baking dough prepared from maize flour. In parts of Bengal and Bihar people eat a roasted powder of grain and maize called sattoo, which is mixed with water and swallowed as such without any further cooking. All these diets are sloppy and tend to be bolted down. Ulcer is common in areas where such diets are eaten. Western diets, although so different from these diets in their content, have in common this sloppiness and a tendency to be bolted down.

On the other hand, in the plains of the Punjab and the United Provinces, thick wheat roti, wheat or millet pratha and roti or wheat fried pooree (Uttar Pradesh, Rajputana, Gujerat) or thick nan made from wheat flour; baked or fried Bhattooras or tandoori roti (Punjab and Delhi) or the thick fried maize bread are eaten. All these have one thing in common: they cannot be bolted down and require thorough mastication and mixing with the saliva.

In the villages of the Punjab roti is commonly made from a mixture of wheat and graim flours which 
TABLE I

ULCER ADMISSIONS IN PRESENT SERIES

\begin{tabular}{|c|c|c|c|c|c|}
\hline Place & $\begin{array}{l}\text { Relative Humidity } \\
\text { (mean annual \%) }\end{array}$ & $\begin{array}{l}\text { Ulcer } \\
\text { Admissions }\end{array}$ & $\begin{array}{l}\text { Admissions } \\
\text { for all } \\
\text { Diseases }\end{array}$ & $\begin{array}{l}\text { Percentage of } \\
\text { Ulcer } \\
\text { Admissions }\end{array}$ & Perforations \\
\hline Jaipur & 55 & - & $442^{1}$ & - & - \\
\hline Bikaner & 55 & - & $313^{1}$ & - & - \\
\hline Kota & 54 & - & 1,337 & - & - \\
\hline Jodhpur & 55 & - & 1,892 & - & - \\
\hline Ferozepur & 65 & 1(?) & 1,348 & $0.07(?)$ & - \\
\hline Hissar & 60 & - & - & - & - \\
\hline Bandikui & 60 & - & 761 & - & - \\
\hline New Delhi & 61 & 4 & 5,258 & 0.07 & - \\
\hline Jhansi & 58 & - & 2,226 & - & - \\
\hline Ajmer & 57 & 2 & 3,070 & 0.06 & - \\
\hline Bhavnagar & 61 & 3 & 1,112 & 0.2 & - \\
\hline Amritsar & 66 & - & 500 & - & - \\
\hline Nagpur & 59 & - & 1,400 & - & - \\
\hline Baroda & 69 & 1 & 912 & $0 \cdot 1$ & - \\
\hline Bombay & 79 & 25 & 3,269 & 0.3 & 4 \\
\hline Bhusawal & 72 & 30 & 3,534 & 0.9 & 7 \\
\hline Asansol & 72 & 54 & 8,953 & 0.6 & 2 \\
\hline \multicolumn{6}{|c|}{ South India (whole of the } \\
\hline Southern Railway) & 88 & 1,629 & 19,801 & $8 \cdot 2$ & 27 \\
\hline Calcutta & 82 & 86 & 5,787 & $1 \cdot 5$ & 8 \\
\hline Gauhati (Assam) & 84 & 87 & 1,915 & $4 \cdot 5$ & 5 \\
\hline Lumding (Assam) & 86 & 59 & 1,864 & $3 \cdot 1$ & 8 \\
\hline Dibrugarh (Assam) & 88 & 120 & 2,752 & $4 \cdot 3$ & 1 \\
\hline Udaipur (Rajputana) & - & 132 & 9,971 & $1 \cdot 4$ & 3 \\
\hline
\end{tabular}

${ }^{1}$ Average outpatients daily-new cases

TABLE II

ULCER PREVALENCE REPORTED IN OTHER SERIES

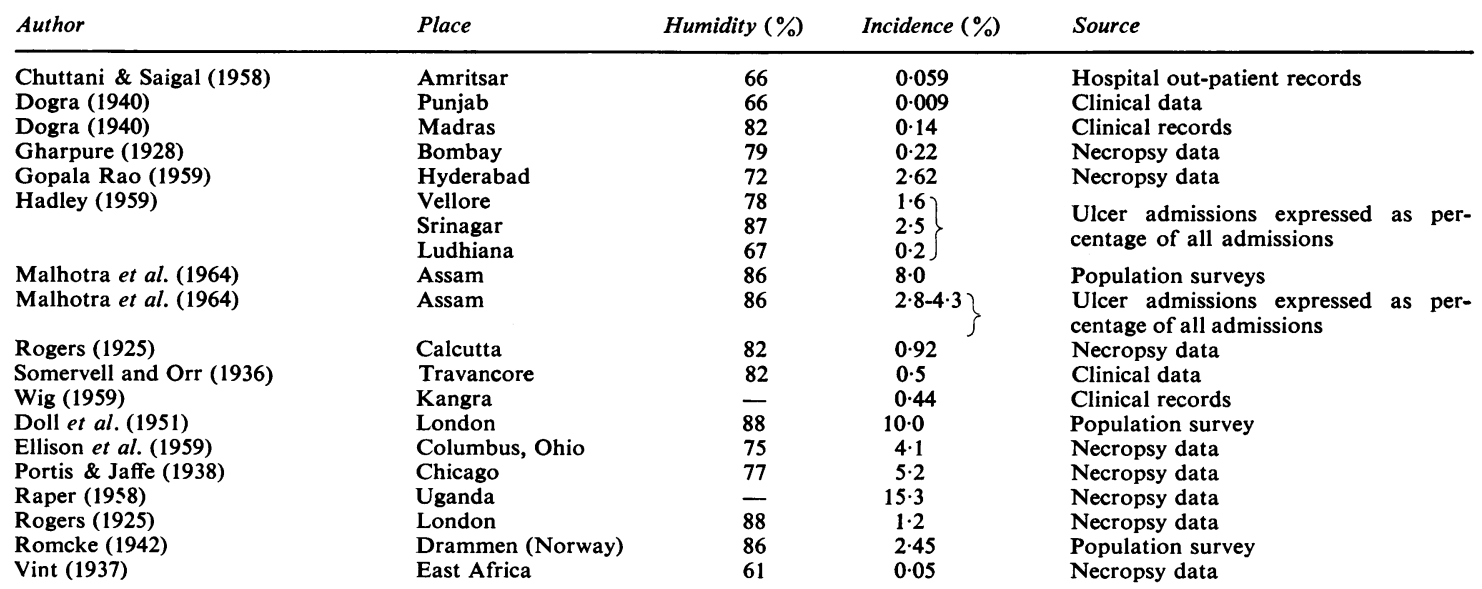

also aids excessive salivation and requires thorough mastication.

Rice is also eaten in the Punjab on occasion but the way it is cooked, which involves long frying to prepare pullao or biryani, renders the rice such that it cannot be bolted down and has to be chewed and masticated before swallowing.

Sweets are eaten all over the country. But here again the regional differences are striking. The ras goola, chamcham, and rosh malai of Assam and Bengal and the jalebi, pera, pinnee, and sohan halwa of the Punjab and the United Provinces, illustrate this difference characteristically. The effect on salivation of the western jelly, trifle, or custard pudding as compared to the Punjabi rabari, sohan halwa, and jalebi is obvious. One has only to eat these various types of sweets to realize that one produces hardly any saliva whereas the other cannot be bolted down and has to be chewed and masticated well, giving rise to excessive saliva of a slimy consistency.

Chewing betel nut and paan leaf is a universal 
FIG. 1

I Bombay

2 Kota

3 Ferozepur

4 New Delhi

5 Jhansi

6 Ajmer

7 Bhavnagar

8 Amritsar
DIAGRAMATIC MAP OF THE SUB-CONTINENT

IIIM Peptic ulcer regions

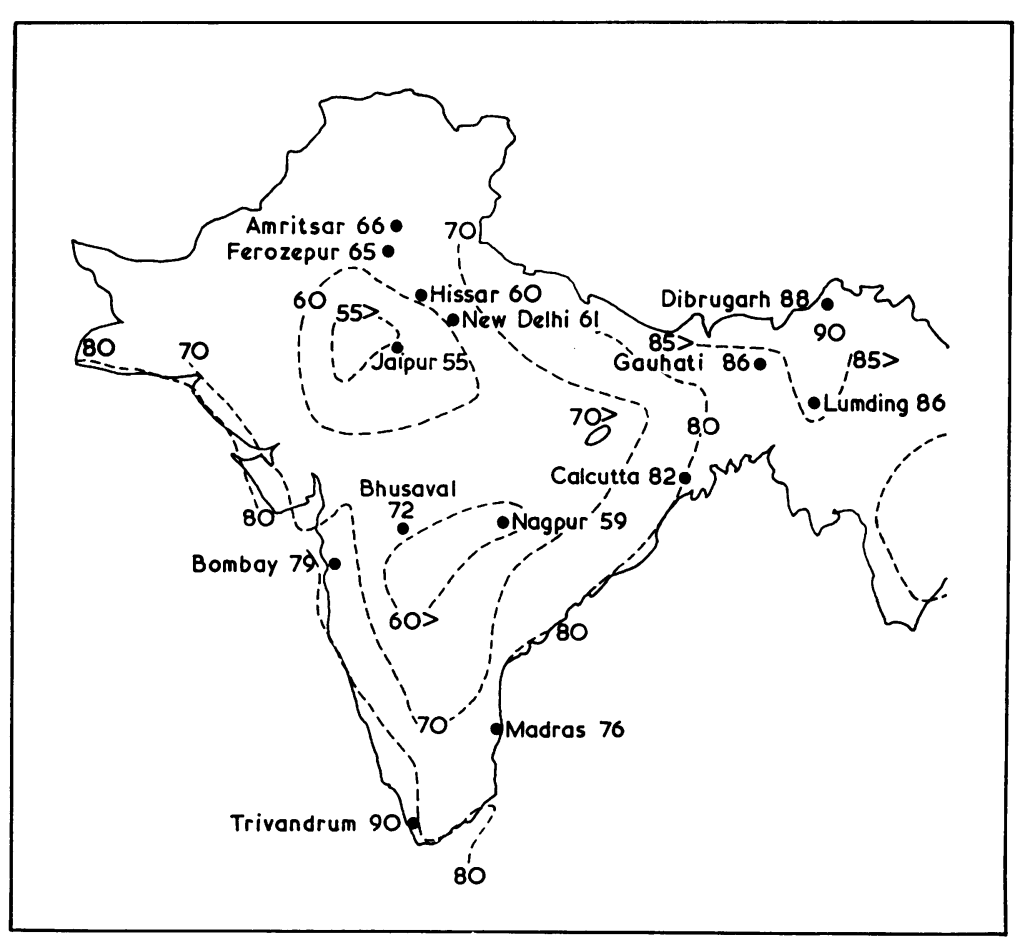

9 Srinagar

10 Nogpur

(I) Gouhati

12 Lunding

13 Barode

14 Udaipur

15 Bhusaval 
habit in India. Here again the regional differences are as remarkable. The betel nut of Assam and Kerala called tambul is soft and irritant and tends to be swallowed without giving rise to much salivation. The sweet betel nut and paan of the Punjab, the United Provinces, and Rajasthan, on the other hand, is stony hard, dry and astringent and its chewing produces much thick and viscid saliva.

The regional differences in the consumption of milk are also interesting. In the Punjab, milk is taken very hot and with a lot of thick cream in it so that it has to be drunk in small sips which have to be rolled in the mouth to cool causing a free flow of slimy saliva. Another way the milk is taken in the arid regions of the Punjab and Rajasthan is to mix it with sweets like jalebi or pera. This milk 'cocktail' is taken hot and it produces a free flow of saliva of a thick and slimy consistency. In South India, in Maharashtra and in parts of Gujarat, it is taken as a thin and watery buttermilk either alone or mixed with rice. This hardly produces any salivation. In the western countries where the average per capita consumption of milk is perhaps higher than in the Punjab, milk is generally taken cold as a long drink.

\section{CONCLUSIONS AND THEORIES ON THE AETIOLOGY OF} ULCER

HUMIDITY Data in Tables I and II show that there is a correlation between ulcer prevalence and mean relative humidity, the incidence of ulcer being high in areas where humidity is also high. Konstam (1954) in his Nigerian study has also made a similar observation, ulcer being more common in the green wet parts of Nigeria whereas the disease is practically unknown in the arid southern regions. Ulcer is common in Britain, Norway, Germany, Assam, Kashmir, and the south of India and the wet parts of Africa, such as Ghana and Uganda, and in Peru. The relative humidity of London is $93 \%$, Oslo $91 \%$, Hamburg $90 \%$, Trivandrum (south India) $82 \%$, Lumding (Assam) 86\%, Sierra Leone 85\%, Accra (Ghana) $85 \%$, Lagos (Nigeria) $90 \%$, and Lima (Peru) $85 \%$. Data presented in Table II from other sources show a similar correlation. It is, therefore, reasonable to postulate that ulcer is more common in humid climates than in arid regions. Yet humidity does not appear to be the cause of ulcer. Eagle and Gillman (1938) found that in Johannesburg (humidity $77 \%$ ) ulcers were seven times more common in Europeans than in Bantus. In a survey of the Punjabi sweepers (income Rs.100 or $£ 7$ per month) settled in Assam (humidity $86 \%$ ), not a single case of ulcer was found by the writer although the incidence in the local Assamese or Bengalee population was $8 \%$ of the adult population. Kouwenaar (1930) found a similar racial variability in Java where ulcers were more than a hundred times more commonly found in necropsy material in the Chinese than in the Javanese labourers, the relative frequencies being $10.1 \%$ and $0.6 \%$ respectively. It is seen from our data that wherever the humidity is high, people eat soft foods which do not require much mastication and therefore do not produce much saliva.

DIET Ulcers have been ascribed in various parts of the world to hot foods, spices, fasting, overeating, excessivestarch, alcohol, coffee and tea, and to smoking. Somervell and Orr (1936) and Hadley (1959) believed that hot foods, tapioca, chillies, and condiments contributed to the high incidence in the south of India. This belief cannot be correct as in this study we have found that a lot of chillies and condiments are eaten also in the Punjab and the plains of Rajasthan where the incidence of ulcer is low. Konstam (1954) ascribed the high incidence in his Nigerian study to vitamin B deficiency. Pulvertaft (1959) has observed that ulcer in his series was more common in populations which consumed more sweets and sugar. In Africa, China, and south-east Asia, a suspicion seems to have been established that the carbohydrate diets taken there may be contributory, a view supported by higher mortality rates from ulcer in Japan, Chile, and India where similar starchy diets are taken. Against this is the high ulcer prevalence in England, Scotland, Norway, and Australia where the diets are well-balanced and rich in protein. Although May (1958), analysing the limited data at his disposal, was unable to relate diets to regional ulcer prevalence, it appears from the present study that it is not only what is eaten but how it is eaten that is important.

It is probable that saliva, by virtue of its blood group substances, or some other unrecognized factors, which, when adequately supplied to the stomach and duodenum, protect these organs from ulceration. Bolted and hurried meals may produce minor trauma in the mucosa but if adequate salivary secretions are present in the food due to the capacity of saliva to accelerate coagulation, these minor injuries will heal. Or, perhaps, as has been suggested by Aird (1961), the importance of these specific blood group substances in peptic ulcer depends upon some interaction in the cell membrane itself. Such a reaction might well have an immunological basis. The food and the way it is eaten seems to have an important bearing on the aetiology of ulcer. Why then is the disease more common in men than in women who eat the same kind of food?

ROLE OF PARASYMPATHETIC ACTIVITY The overaction of the vagus nerve has been held responsible 
for ulcer formation. The fact that vagotomy promotes healing supports this view. Parasympathetic activity has various physiological effects which appear to be correlated with the incidence of peptic ulcer.

Salivary secretion The control of salivation is also through the autonomic nervous system, and in general terms it can be said that in animal experiments stimulation of the sympathetic nervous system causes the secretion of a small amount of viscous saliva and the stimulation of the parasympathetic (chorda tympani nerve) produces a copious secretion of watery saliva (Brit.med.J., 1961). In our study we have observed that most foods which require much mastication, and especially hot milk and the hard sweets, produce a viscid salivation, whereas soft or irritant foods cause a copious flow of watery saliva. This has been easy to demonstrate, particularly in the case of the betel nut eaten in Assam and the Punjab, and in the case of hot milk as taken in the Punjab and the thin buttermilk as taken in the south of India. I believe that the thick viscid saliva (sympathetic secretion) is protective whilst the thin and watery saliva (parasympathetic secretion) is ulcerogenic. It is interesting to note that in this study it was observed that people in the Punjab, Uttar Pradesh, Rajasthan, and Jammu use a green twig of a tree, either Neem or acacia, which has a bitter or a salty taste, to cleanse their mouths and teeth. The twig is chewed in the morning and chewing causes an excessive watery salivation which is eliminated by frequent spitting, and at the end of the process the subject induces vomiting by tickling the back of the throat which eliminates the night acid secretions. This practice was not present in Bengalees, Assamese, south Indians, and the Kashmiris who instead used an abrasive tooth powder made from charcoal and common salt for their oral hygiene. The writer has also observed on volunteers that some predominently secrete the thick and viscid saliva while others the thin variety. If this observation is confirmed by others, it may be possible to divide men into parasympathetic dominant or the sympathetic dominant individuals, one group being ulcer prone and the other not so.

Stress and strain Another aspect of parasympathetic overaction is the physiological changes in anger, excitement, worry, suppressed emotions, and sexual excitation. More of the physiological changes in these are believed to be due to parasympathetic overaction (Kinsey, Pomeroy, and Martin, 1953). The role of parasympathetic overaction would also explain the higher incidence of ulcer in males than in females.
Sexually and emotionally, man being the aggressive sex, probably carries more of these parasympathetic burdens than the woman and, therefore, is also more prone to get ulcer.

I am grateful to my colleagues, the chief medical officers of the Indian Railways, for the clinical data pertaining to their workers presented in the study. The climatological map has been supplied by the Colaba Observatory, and I am indebted to them for this. I wish to thank especially Dr. K. N. Rao, Director, Colaba Observatory, for his invaluable assistance.

\section{REFERENCES}

Aird, I. (1961). ABO blood groups and gastro-intestinal disease. In Modern Trends in Gastroenterology, 3rd ser., edited by W. I. Card, pp. 49-63. Butterworths, London.

British Medical Journal (1961). Any questions? Excessive glutinous saliva. 2, 189.

Chuttani, P. N., and Saigal, A. K. (1958). J. Ass. Phycns India, 6, 347-349.

Dogra, J. R. (1940). Studies on peptic ulcer in South India. I. Introduction and clinical study of 258 cases. Ind. J. med. Res., 28, 145-161.

Doll, R., Jones, F. Avery, and Buckatzsch, M. M.(1951). Occupational factors in the aetiology of gastric and duodenal ulcers. Spec. Rep. Ser. med. Res. Coun. (Lond.), no. 267.

Eagle, P. C., and Gillman, J. (1938). The incidence of peptic ulcer in the South African Bantu. S. Afr. J. med. Sci., 3, 1-6.

Ellison, E. H., Abrams, J. S., and Smith, D. J. (1959). Post mortem analysis of 812 gastroduodenal ulcers. Amer. J. Surg., 97, 17.

Gharpure, P. V. (1928). Pathological evidence bearing on the incidence of diseases in Bombay. Ind. med. Gaz., 63, 253-259.

Gopala Rao, V. (1959). A note on the problem of peptic ulcer in Hyderabad. Ind. Coun. med. Res. Rep., no. 39, 16-26.

Hadley, G. G. (1959). Studies of peptic ulcer as found in South India. Ibid., no. 39, 31-33.

Kinsey, A. C., Pomeroy, W. B., and Martin, C. E. (1953). Sexual Behaviour in the Human Female. Saunders, Philadelphia.

Konstam, P. G. (1954). Peptic ulceration in Southern Nigeria. Lancet, 2, 1039.

Kouwenaar, W. (1930). Beteekenis van het voa-komen van maagzweren in de tropen voor de studie der aetiologie. (Peptic ulcer in Java). Ned. Geneesk., 74, 2321-2325.

Malhotra, S. L., Majumdar, C. T., and Bardoloi, P. C. (1964). Peptic ulcer in Assam. Peptic ulcer in Assam, Gut, 5, 355-358.

May, J. M. (1958). Report on the geography of peptic ulcers. Schweiz. Z. Path. Bakt., 21, 169-209.

Portis, S. A., and Jaffe, R. H. (1938). J. Amer. med. Ass., 110, 6-13.

Pulvertaft, C. N. (1959). The incidence of peptic ulcer in town and country. In Proceedings of the World Congress of Gastroenterology, Washington, 1958, p. 364-367. Williams \& Wilkins, Baltimore.

Raper, A. B. (1958). The incidence of peptic ulceration in some South African tribal groups. Trans. roy. Soc. trop. Med. Hyg., 52, 535-546.

Rogers, Sir L. (1925). Pathological evidence bearing on disease incidence in Calcutta. Glasg. med. J., 103, 95-114.

Romcke (1942). Quoted by G. Watkinson (1961) In Modern Trends in Gastroenterology, 3rd ser., edited by W. I. Card, p. 35.

Somervell, T. H., and Orr, I. M. (1936). Some contributions to the causation, pathology, and treatment of duodenal ulcer and its complications. Brit. J. Surg., 24, 227-245.

Vint, F. W. (1937). Post-mortem findings in the natives of Kenya E. Afr. med. J., 13, 332-340.

Wig, K. L. (1959). A note on the problem of peptic ulcer in the Punjab. Ind. Coun. med. Res. Rep., no. 39, 70-72. 